\title{
HUKUM ADMINISTRASI DAN SISTEM PERADILAN DI INDONESIA YANG BERKEADILAN SESUAI ASAS-ASAS PANCASILA
}

\author{
Kukuh Sudarmanto \\ Magister Hukum Universitas Semarang, Semarang \\ kukuhsudarmantousm@gmail.com
}

\begin{abstract}
Abstrak
Tujuan dari penelitian ini adalah untuk mengetahui bagaimana hukum administrasi dan sistem peradilan di Indonesia yang berkeadilan sesuai asas-asas Pancasila, serta sinergitasnya dalam hukum administrasi. Indonesia yang berlandaskan pada Pancasila dan UUD 1945, selayaknya pula bahwa tujuan dari administrasi negaranya berdasar dan bersumber pada nilai-nilai Pancasila dan UUD 1945. Metode penelitian yang digunakan adalah penelitian kualitatif. Hasil penelitian menunjukkan bahwa hukum administrasi dan sistem peradilan di Indonesia yang berkeadilan sesuai asas-asas Pancasila merupakan kristalisasi nilai-nilai yang hidup dan berkembang dalam masyarakat sejatinya menjadi sumber utama dalam pembentukan hukum administrasi pemerintahan. Landasan ideal yang terformulasi sebagai dasar negara dan terumus dalam lima sila pada hakikatnya mengandung ajaran moral bangsa, ajaran tentang akhlak, bagaimana seseorang bertingkah laku yang baik, yang beretika, bersusila. Sinergitas asas-asas Pancasila sangat relevan dengan hukum administrasi dengan cita-cita bernegara dalam mewujudkan demokrasi yang berpijak pada politik dan nomokrasi yang berpijak pada kedaulatan hukum, sehingga semangat bernegara yang terilhami dalam lima sila Pancasila dalam diwujudkan dalam kehidupan berbangsa dan bernegara.
\end{abstract}

Kata kunci: Asas Pancasila; Hukum Administrasi; Sistem Peradilan

\section{THE EQUITABLE ADMINISTRATIVE LAW AND JUDICIAL SYSTEM IN INDONESIA THAT SUITABLE WITH PRINCIPLES OF PANCASILA}

\begin{abstract}
The purpose of this study is to find out how the administrative law and justice system in Indonesia are fair according to the principles of Pancasila, and their synergy in administrative law. Indonesia which is based on Pancasila and the 1945 Constitution, it is also appropriate that the objectives of its state administration are based on and sourced from the values of Pancasila and the 1945 Constitution. The research method used is qualitative research. The results of the study indicate that the administrative law and judicial system in Indonesia that is just according to the principles of Pancasila is a crystallization of values that live and develop in society, which is actually the main source in the formation of government administrative law. The ideal foundation formulated as the basis of the state and formulated in the five precepts essentially contains the nation's moral teachings, teachings on morals, how a person behaves well, is ethical, and has morality. The synergy of the principles of Pancasila is very relevant to administrative law with the ideals of the state in realizing a democracy that is based on politics and nomocracy based on the rule of law, so that the spirit of state inspired in the five precepts of Pancasila is realized in the life of the nation and state.
\end{abstract}

Keywords: Pancasila Principle; Administrative Law； Judicial System 


\section{PENDAHULUAN}

\section{A. Latar Belakang}

Pancasila sebagai ideologi berhakikat sebagai sistem nilai bangsa Indonesia. Sistem nilai seperti ini dipandang oleh studi filsafat yang secara historik digali pada budaya bangsa dan ditempa oleh penjajahan, yang kemudian diterapkan pada wilayah yuridis kenegaraan sebagai pedoman bermoral, berhukum, dan berpolitik dalam kehidupan bermasyarakat, berbangsa, dan bernegara. ${ }^{1}$ Pelaksanaan administrasi pemerintahan tidak terlepas dari konsep negara hukum. Dalam negara hukum setiap tindakan yang dilakukan oleh warga negara dan penyelenggara pemerintahan berdasarkan atas hukum. Di sini hukum sebagai ukuran setiap penyelenggaraan berbangsa dan bernegara.

Berdasarkan Pasal 1 ayat (3) UUD 1945 menyakatan bahwa Indonesia adalah negara hukum. Dengan demikian, terdapat hubungan korelatif antara penyelenggaraan pemerintahan yang harus berdasarkan atas hukum dengan negara yang berdasarkan atas hukum. Kedua konsep tersebut tidak dapat dipisahkan karena berbicara tentang pemerintahan pada saat yang bersamaan membicarakan tentang negara, begitu sebaliknya. Negara hukum Indonesia dapat diibaratkan sebagai sebuah proyek rumah, di mana dia harus dibangun, kemudian dirawat, lalu diwariskan pada penerusnya. Diperlukan penemuan jati diri atau identitas dalam pembentukannya. Dilihat dari sisi sejarah Indonesia mengikuti langkah rechtsstaat atau civil law, karena Indonesia cukup lama dijajah oleh Belanda. ${ }^{2}$

Bila dikaji lebih mendalam, sebenarnya Indonesia bukan sekedar negara yang berdasarkan atas hukum yang pengertiannya masih umum, melainkan Indonesia berdasarkan atas hukum Pancasila. Indonesia yang berlandaskan pada Pancasila dan UUD 1945, selayaknya pula bahwa tujuan dari administrasi negaranya berdasar dan bersumber pada nilai-nilai Pancasila dan UUD 1945 dimana dalam pembukaannya disebutkan bahwa negara Indonesia bertujuan untuk melindungi segenap bangsa Indonesia, mencerdaskan kehidupan bangsa, mewujudkan keadilan sosial, memajukan kesejahteraan umum dan ikut serta dalam usaha perdamaian dunia.

Berbagai tujuan negara sebagai mana diuraikan di atas, yang kemudian tujuan tersebut dilaksanakan oleh pihak pemerintahan sebagai unsur negara, maka tugas administrasi pemerintahan/negara adalah memberikan pelayanan yang baik kepada kepentingan masyarakat, bangsa dan negara, serta mengabdi kepada kepentingan masyarakat. Bukan sebaliknya yang seringkali terjadi masyarakat yang harus

1 Fransiska Novita Eleanora, "Pancasila Sebagai Norma Dasar Dalam Sistem Hukum Indonesia," ADIL: Jurnal Hukum 3, no. 1 (2019): 141, https://doi.org/10.33476/ajl.v3i1.838.

2 Arif Hidayat and Zaenal Arifin, "Politik Hukum Legislasi Sebagai Socio-Equilibrium Di Indonesia," Jurnal Ius Constituendum 4, no. 2 (2019): 147-59, https://doi.org/10.26623/jic.v4i2.1654. 
melayani pihak yang berkuasa. Untuk itu agar penyelenggaraan administrasi negara ini dapat berjalan sesuai dengan tujuan dan cita-cita bangsa, maka dituntut peran serta masyarakat. Dukungan dari masyarakat kepada penyelenggara pemerintahan melalui pengawasan dari masyarakat terhadap kinerja yang dilakukan serta harus ada pertanggung jawaban dari kegiatan yang dilakukan tersebut.

Keadilan untuk masyarakat majemuk seperti Indonesia belum juga dapat disepakati. Persoalannya adalah bentuk keadilan tidak sejalan dengan pemahaman dan penilaian tentang keadilan. Keadilan merupakan suatu hal yang sangat sulit untuk diwujudkan. Keadilan merupakan dambaan bagi manusia untuk mendapatkan suatu kehidupan yang layak, yang terpenuhinya hak-hak mereka dalam menjalani kehidupan. Dalam menjalankan kehidupan, manusia merupakan mahkluk sosial yang tidak lepas dari kelemahan dan kekurangan. Kelemahan dan kekurangan inilah yang menyebabkan keadilan itu sulit untuk diwujudkan karena keadilan adalah milik Tuhan Yang Maha Esa.

Hukum merupakan alat untuk menciptakan keadilan. Keadilan di dalam hukum merupakan keadilan yang didambakan bagi seluruh masyarakat yang hidup di dalam bingkai hukum itu sendiri. ${ }^{3}$ Oleh karena itu, hukum memerlukan dasar dalam membentuk keadilan yang dapat diterima oleh masyarakat banyak. Banyaknya permasalahan tentang hukum, terutama permasalahan dalam pembentukan peraturan perundang-undangan menimbulkan permasalahan dalam mencapai keadilan. Hukum masih menjadi keinginan politik semata, bukan merupakan keinginan masyarakat pada umumnya. Dengan menggunakan landasan fundamental norm yaitu Pancasila dalam pembentukan hukum yang baik, maka Pancasila selalu dan harus dijadikan tonggak utama dalam membentuk peraturan perundang-undangan yang sesuai dengan jiwa bangsa Indonesia yang memanusiakan manusia yang adil dan beradab serta berkeadilan sosial bagi seluruh rakyat Indonesia.

Penelitian sebelumnya yang relevan dengan penelitian ini diangkat oleh Bo'a (2018) menjelaskan bahwa keberadaan Pancasila sebagai sumber segala sumber hukum dalam tatanan hukum nasional masih belum dapat diterapkan secara praksis. Pengaruh reformasi ternyata membuat status Pancasila dalam tatanan hukum mengalami ketergerusan. Perbedaan penelitian Bo'a dengan artikel ini adalah pada permasalahan yang dikaji. Penelitian Bo'a mengkaji tentang “keberadaan Pancasila sebagai sumber segala sumber hukum, pengaruh reformasi terhadap keberadaan Pancasila sebagai sumber segala sumber hukum, serta upaya memperkuat dan menerapkan Pancasila sebagai sumber segala sumber hukum dalam sistem hukum

3 Dani Pinasang, "Falsafah Pancasila Sebagai Norma Dasar (Grundnorm) Dalam Rangka Pengembanan Sistem Hukum Nasional,” Jurnal Hukum UNSRAT 20, no. 3 (2013). 
nasional." Sedangkan pada penelitian ini mengkaji tentang hukum administrasi dan sistem peradilan di Indonesia yang berkeadilan sesuai asas-asas Pancasila, serta sinergitasnya dalam hukum administrasi.

Selanjutnya pada penelitian Atmadja (2018) yang berjudul "Asas-Asas Hukum Dalam Sistem Hukum." Penelitian ini menjelaskan tentang "analisis pengertian asas-asas hukum, perbedaan asas hukum dengan norma/kaidah hukum, kedudukan asas hukum, fungsi dan jenis asas-asas hukum dalam sistem hukum." Hasil dari penelitian ini menjelaskan bahwa Pancasila merupakan sumber segala sumber hukum negara, maka Pancasila harus dapat dipegang teguh sebagai kaidah dasar, sebagai suatu beginsel atas asas ideologi hukum Indonesia. ${ }^{5}$

Penelitian selanjutnya yang ditulis oleh Zaman (2015), penelitian tersebut berjudul "Membangun Politik Hukum Administrasi Pemerintahan Yang Bersumber Dari Nilai-Nilai Pancasila," tersebut membahas tentang politik hukum adminitrasi pemerintahan yang terdapat dalam Undang-undang Nomor 30 Tahun 2014 tentang Administrasi Pemerintahan, dan membangun politik hukum administrasi pemerintahan yang bersumber dari nilai-nilai Pancasila. Hasil penelitian ini menyebutkan bahwa semua badan dan lembaga yang menjalankan fungsi pemerintahan harus mengacu pada asas-asas umum pemerintahan yang baik sebagai bentuk adanya perlindungan hukum bagi penyelenggara pemerintahan dan masyarakat. ${ }^{6}$

Penelitian ini melengkapi penelitian sebelumnya dimana dalam penelitian Bo'a hanya mengkaji tentang bagaimana Pancasila sebagai sumber segala sumber hukum di Indonesia, sedangkan penelitian Atmadja lebih fokus mengkaji tentang analisis asas -asas Pancasila. Berbeda dengan penelitian Zaman yang mengkaji tentang politik hukum administrasi negara yang bersumber pada Pancasila. Perbedaan penelitian ini dengan penelitian sebelumnya yaitu dari permasalahan yang diangkat dalam penelitian ini mengkaji tentang hukum administrasi dan sistem peradilan di Indonesia yang sesuai dengan asas keadilan dalam Pancasila dan bagiamana sinergitas asas-asas Pancasila dalam hukum administrasi. Hal tersebut juga yang menjadi tujuan dari penelitian ini.

\section{B. Permasalahan}

Adapun permasalahan yang akan dikaji pada artikel ini adalah bagaimana hukum administrasi dan sistem peradilan di Indonesia yang berkeadilan sesuai asas-

\footnotetext{
${ }^{4}$ Fais Yonas Bo'a, "Pancasila Sebagai Sumber Hukum Dalam Sistem Hukum Nasional Pancasila as the Source of Law in the National Legal System," Jurnal Konstitusi 15, no. 1 (2018): 27-49, https://doi.org/https://doi.org/10.31078/jk1512.

5 Dewa Gede Atmadja, “Asas-Asas Hukum Dalam Sistem Hukum,” Kertha Wicaksana 12, no. 2 (2018): 145-55, https://doi.org/https://doi.org/10.22225/kw.12.2.721.145-155.

${ }^{6}$ Nurus Zaman, "Membangun Politik Hukum Administrasi Pemerintahan Yang Bersumber Dari NilaiNilai Pancasila," Rechtldee 10, no. 2 (2015): 203-22, https://doi.org/https://doi.org/10.21107/ri.v10i2.1237.
} 
asas Pancasila? serta bagaimana sinergitas asas-asas Pancasila dalam hukum administrasi?

\section{Metode Penelitian}

Metode penelitian yang digunakan adalah penelitian kualitatif yaitu "penelitian yang dimaksudkan untuk memahami fenomena tentang apa yang dialami oleh subyek penelitian, misalnya perilaku, persepsi, tindakan dan lainnya, secara holistik dengan cara deskripsi dalam bentuk kata-kata naratif pada suatu konteks khusus alamiah dan dengan memanfaatkan metode ilmiah." " Jenis data yang digunakan yaitu "sumber data sekunder yaitu data yang diperoleh atau dikumpulkan oleh orang yang melakukan penelitian dari sumber-sumber yang telah ada." Data sekunder diperoleh dengan penelitian kepustakaan guna mendapatkan landasan teoritis berupa pendapat-pendapat atau tulisan-tulisan para ahli atau pihakpihak lain yang berwenang dan juga untuk memperoleh informasi baik dalam bentuk ketentuan-ketentuan formal maupun data melalui nahkah resmi yang ada.

\section{PEMBAHASAN DAN HASIL PENELITIAN}

\section{A. Hukum Administrasi Dan Sistem Peradilan Di Indonesia Yang Berkeadilan Sesuai Asas-Asas Pancasila}

Bagi negara demokrasi, hukum administrasi negara menjadi alat bagi pejabat negara dan rakyat yang mempunyai kedudukan yang sejajar dalam pemerintahan. Demokrasi akan menciptakan kesejahteraan, dimana hukum bagi negara demokrasi sebagai konstruksi politik yang menjalankan fungsinya sebagai sarana dalam meningkatkan kesejahteraan masyarakat. ${ }^{8}$

Pancasila bersifat fleksibel, mengikuti perkembangan jaman yang ada. Beberapa ahli berpendapat berbeda tentang hakikat dari Pancasila, tergantung dari kebutuhan keilmuan yang mereka gunakan. Akan tetapi, untuk mengkaji dan meneliti hakikat dari Pancasila tentunya perlu pemahaman yang sama oleh para ahli, sehingga tidak memunculkan multi tafsir dalam memaknai hakikat dari Pancasila. Tentunya hakikat keadilan di dalam Pancasila harus dijabarkan dalam bentuk norma hukum yang bebas dari kepentingan pribadi maupun golongan. Perwujudan kebenaran dari Pancasila ke dalam norma hukum, tentunya Pancasila mampu memberikan nilai tersendiri tentang keadilan dalam mewujudkan keadilan hukum bagi bangsa Indonesia. Keadilan hukum yang bersumber dari Pancasila, diharapkan mampu memberikan pengertian tentang arti kebenaran keadilan yang sesungguhnya, yang berasal dari bangsa kita sendiri, bukan warisan dari bangsa asing. Keadilan berdasarkan Pancasila harus diwujudkan, dijabarkan, dan direalisasikan ke dalam norma hukum Indonesia agar terwujud keadilan yang

${ }^{7}$ Lexy J Moleong, Metode Penelitain Kualitatif (Bandung: PT Remaja Rosda Karya, 2016).

${ }^{8}$ Lismanto Lismanto and Yos Johan Utama, "Membumikan Instrumen Hukum Administrasi Negara Sebagai Alat Mewujudkan Kesejahteraan Sosial Dalam Perspektif Negara Demokrasi," Jurnal Pembangunan Hukum Indonesia 2, no. 3 (2020): 416-33, https://doi.org/10.14710/jphi.v2i3.416-433. 
memberikan perlindungan hak dan kewajiban bagi seluruh rakyat Indoensia dalam bentuk peraturan perundang-undangan.

Pasal 1 ayat (2) Undang-Undang Dasar Negara Republik Indonesia Tahun 1945, kedaulatan berada di tangan rakyat dan dilaksanakan menurut UndangUndang Dasar. Selanjutnya menurut ketentuan Pasal 1 ayat (3) Undang-Undang Dasar Negara Republik Indonesia Tahun 1945, negara Indonesia adalah negara hukum. Hal ini berarti bahwa sistem penyelenggaraan pemerintahan negara Republik Indonesia harus berdasarkan atas prinsip kedaulatan rakyat dan prinsip negara hukum. ${ }^{9}$ Pancasila sebagai dasar negara mempunyai sifat imperatif/memaksa, artinya setiap warga negara wajib tunduk taat kepadanya. ${ }^{10}$

Peraturan perundang-undangan yang baik adalah "peraturan perundangundangan yang memenuhi syarat dasar pembentukan peraturan perundangundangan yang dimiliki oleh bangsa Indonesia. Hal ini harus sesuai dengan keadilan berdasarkan Pancasila," agar terwujud keadilan hukum yang diakui oleh seluruh bangsa Indonesia tanpa meragukan bentuk keadilan hukum yang ada, karena keadilan hukum dibentuk berdasarkan prinsip-prinsip pembentukan peraturan perundang-undangan yang berdasarkan keadilan Pancasila. Tentunya dasar pembentukan peraturan perundang-undangan yang berdasarkan keadilan Pancasila harus ditemukan dengan pemikiran dan pemahaman mendalam tentang kebenaran Pancasila sebagai dasar falsafah dan ideologi bangsa.

Konsep negara hukum barat, baik rechtsstaat maupun rule of law lahir dikarenakan adanya pergulatan sosial yang menentang adanya absolutisme yang dilakukan oleh para raja pada waktu itu. Sedangkan negara hukum Indonesia lahir bukan karena adanya pergulatan sosial melawan absolutisme sebagaimana yang terjadi di negara rechtsstaat maupun rule of law. ${ }^{11}$

Menurut Anggara, filsafat Pancasila adalah "hasil berpikir atau pemikiran yang sedalam-dalamnya dari bangsa Indonesia yang oleh bangsa Indonesia yang di anggap, dipercaya dan diyakini sebagai sesuatu (kenyataan, norma-norma,nilainilai) yang paling benar, paling adil, paling bijaksana, paling baik dan paling sesuai bagi bangsa Indonesia." 12 Pancasila sebagai dasar negara, artinya Pancasila dijadikan sebagai dasar untuk mengatur penyelenggaraan pemerintahan negara. Pancasila menurut Ketetapan MPR Nomor III/MPR/2000 merupakan "sumber

\footnotetext{
9 Iskatrinah, "Pergeseran Kompetensi Peradilan Tata Usaha Negara Pasca Diundangkan UndangUndang Nomor 30 Tahun 2014 Tentang Administrasi Pemerintahan," Jurnal Media Komunikasi Pendidikan Pancasila Dan Kewarganegaraan Volume 2, no. 1 (2020): 200-207, https://doi.org/https://doi.org/10.23887/jmpppkn.v2i1.137.

10 A. Syafi' AS, "Pengaruh Nilai-Nilai Pancasila Dan Ajaran Islam Terhadap Tujuan Pendidikan Nasional," Jurnal Sumbula 1, no. 1 (2016).

${ }^{11}$ Suparwi Widiatama, Hadi Mahmud, "Ideologi Pancasila Sebagai Dasar Membangun Negara Hukum Indonesia," Jurnal USM Law Review 3, no. 2 (2020): 310-27, https://doi.org/http://dx.doi.org/10.26623/julr.v3i2.2774.

12 Syahya Anggara, Hukum Administrasi Negara (Bandung: Pustaka Setia, 2018).
} 
hukum dasar nasional." Dalam kedudukannya sebagai dasar negara maka Pancasila berfungsi sebagai:

1. Sumber dari segala sumber hukum (sumber tertib hukum) Indonesia. Artinya Pancasila merupakan asas kerohanian tertib hukum Indonesia;

2. Suasana kebatinan (geistlichenhinterground) dari Undang-Undang Dasar;

3. Cita-cita hukum bagi hukum dasar negara;

4. Norma-norma yang mengharuskan undang-undang dasar mengandung isi yang mewajibkan pemerintah dan lain-lain penyelenggara negara memegang teguh cita-cita moral rakyat yang luhur;

5. Sumber semangat bagi Undang-Undang Dasar 1945, penyelenggara negara, pelaksana pemerintahan. MPR dengan Ketetapan No. XVIIV MPR/1998 telah mengembalikan kedudukan Pancasila sebagai dasar negara RI. ${ }^{13}$

Di dalam substansi Pancasila terkandung nilai-nilai yang positif yang mampu memberikan perubahan bagi bangsa ini. Nilai-nilai positif ini mampu memberikan landasan bagi terciptanya suatu keadilan bagi bangsa Indonesia. Relevansi dengan keadilan maka nilai keadilan yang terkandung di dalam Pancasila dapat menjadi landasan dasar bagi terbentuknya hukum yang berkemanusiaan yang adil dan beradab serta berkeadilan sosial bagi seluruh rakyat Indonesia. Kemanusiaan yang adil dan beradab merupakan dasar dari perlindungan hak asasi yaitu memanusiakan manusia secara beradab tanpa mengurangi haknya sedikitpun. Sedangkan keadilan sosial merupakan keadilan yang digunakan untuk membedakan keadilan sosial dengan konsep keadilan dalam hukum. Keadilan sosial juga merupakan salah satu sila dalam Pancasila yaitu sila kelima dari Pancasila yang dirumuskan dalam Pembukaan Undang-Undang Dasar 1945 alinea keempat.

Menurut Sjachran Basah, mengemukakan bahwa tujuan peradilan administrasi negara (PTUN) ialah "memberikan jaminan pengayoman hukum, tidak hanya untuk rakyat semata-mata melainkan juga bagi administrasi negara dalam arti menjaga dan memelihara keseimbangan kepentingan masyarakat dengan kepentingan individu." 14 Untuk administasi negara akan terjaga ketertiban, ketentraman dan keamanan dalam melaksanakan tugas-tugasnya demi terwujudnya pemerintahan yang kuat, bersih, dan berwibawa dalam negara hukum berdasarkan Pancasila. Negara Indonesia merupakan negara hukum, sebagai "negara hukum, maka perwujudannya adalah adanya kekuasaan kehakiman yang dijalankan oleh setiap lembaga peradilan."

Keputusan Sidang PPKI pada tanggal 18 Agustus 1945 menetapkan UUD sebagai hukum dasar dalam penyelenggaraan negara dan pemerintahan Republik

13 C.S.T Kansil dan Chritine S.T. Kansil, Empat Pilar Berbangsa Dan Bernegara (Jakarta: Rineka Cipta, 2014).

${ }^{14}$ Faisal Faisal, "Membangun Politik Hukum Asas Legalitas Dalam Sistem Hukum Pidana Indonesia," Jurnal Hukum Ius Quia Iustum 21, no. 1 (2014): 81-95, https://doi.org/10.20885/iustum.vol21.iss1.art5. 
Indonesia. Pembukaan UUD 1945 menggariskan dasar negara yaitu Pancasila. Secara yuridis Pancasila adalah sah menjadi dasar negara, maka seluruh kehidupan bernegara dan bermasyarakat haruslah didasari Pancasila. Landasan hukum Pancasila sebagai dasar negara memberi akibat hukum dan filosofis, yaitu kehidupan negara dari bangsa Indonesia harus berpedoman kepada Pancasila. ${ }^{15}$

Pada hakikatnya secara hierarki dalam perundang-undangan yang berlaku di Indonesia, Pancasila merupakan sumber dari segala sumber hukum dalam sistem hukum positif Indonesia. Sebagai sumber dari segala sumber hukum, maka didalamnya mengandung nilai-nilai filosofis yang menaungi setiap peraturan perundang-undangan yang ada. Nilai-nilai filosofis yang terkandung di dalam Pancasila diwujudkan melalui sila-sila yang termaktub dalam Pancasila. Dilihat dari kedudukannya, Pancasila mempunyai kedudukan yang tinggi, yaitu "sebagai cita-cita dan pandangan hidup bangsa dan negara. Dilihat dari fungsinya Pancasila mempunyai fungsi utama sebagai dasar negara. Dilihat dari segi materinya, Pancasila digali dari pandangan hidup bangsa Indonesia yang merupakan jiwa dan kepribadian bangsa Indonesia."16

Mengenai Pancasila sebagai dasar negara Notonogoro menyatakan diantara unsur-unsur pokok kaidah negara yang fundemental, asas kerohanian Pancasila adalah "mempunyai kedudukan istemewa dalam hidup kenegaraan dan bangsa Indonesia. Selanjutnya dikatakan, norma hukum yang pokok dan disebut pokok kaidah fundemental daripada negara itu dalam hukum mempunyai hakikat dan kedudukan yang tetap, kuat dan tidak berubah bagi negara yang dibentuk, dengan perkataan lain dengan jalan hukum tidak dapat dirubah." "17 Landasan ideal yang terformulasi sebagai dasar negara dan terumus dalam lima sila pada hakikatnya mengandung ajaran moral bangsa, ajaran tentang akhlak, bagaimana seseorang bertingkah laku yang baik, yang beretika, bersusila. Ajaran moral bangsa Indonesia berjumlah lima, yaitu:

(1) Ajaran yang mengakui adanya Tuhan Yang Maha Esa,

(2) Ajaran agar manusia dalam bertingkah laku memperlakukan orang sebagai manusia yang adil dan beradab,

(3) Ajaran yang menghendaki kehidupan dalam persatuan dalam wadah kehidupan berbangsa, bangsa Indonesia,

(4) Ajaran yang mengajarkan kehidupan kerakyatan yang dipimpin oleh hikmah kebijaksanaan, dan

15 Putera Astomo, "Eksistensi Peradilan Administrasi Dalam Sistem Negara Hukum Indonesia," Masalah-Masalah Hukum 43, no. 3 (2014): 363-71, https://doi.org/10.14710/mmh.43.3.2014.363-371.

16 Jimly Asshidqie, Konstitusi Bernegara Praksis Kenegaraan Bermartabat Dan Demokratis (Malang: Setara Press, 2015).

17 Ferry Irawan Febriansyah, "DiH Jurnal Ilmu Hukum” 13, no. 25 (2017): 1-27. 
(5) Ajaran yang menghendaki kehidupan yang berkeadilan sosial bagi seluruh rakyat Indonesia. ${ }^{18}$

Nilai-nilai yang terkandung dalam sila-sila yang ada dalam Pancasila diimplementasikan pada pembentukan peraturan perundang-undangan utamanya di bidang hukum adminitrasi pemerintahan. Menurut Bagir Manan Pancasila sebagai pandangan hidup bangsa dan negara Indonesia karena sudah semestinya demokrasi di Indonesia didasarkan pada Pancasila, maka lahirlah nama baru demokrasi Pancasila yang secara konseptual keseluruhan nilai-nilai Pancasila akan menjadi landasan mekanisme dan sekaligus tujuan demokrasi Indonesia. ${ }^{19}$

Setelah kemerdekaan landasan penyelenggaraan negara Indonesia terdiri atas landasan ideal yaitu Pancasila, landasan konstitusional yaitu UUD 1945 yang telah mengalami 4 (empat) tahap amandemen. Landasan operasional tidak dikenal lagi sejak Garis-Garis Besar Haluan Negara (GBHN) dihapuskan dalam amandemen UUD 1945. Akan tetapi, untuk operasionalisasi dalam mencapai tujuan negara mengacu pada program legislasi nasional yang disepakati bersama oleh Presiden dan DPR. Tujuan penyelenggaraan pemerintahan negara Indonesia adalah "untuk membentuk suatu pemerintahan negara Indonesia yang melindungi segenap bangsa Indonesia dan seluruh tumpah darah Indonesia dan untuk memajukan kesejahteraan umum, mencerdaskan kehidupan bangsa, dan ikut melaksanakan ketertiban dunia yang berdasarkan kemerdekaan, perdamaian abadi dan keadilan sosial.”

Tujuan tersebut dapat diringkas menjadi tujuan nasional dan internasional. hukum administrasi negara mencakup tiga fungsi, yaitu: fungsi normatif, instrumental dan fungsi jaminan. Fungsi normatif menyangkut penormaan kekuasaan pemerintah, fungsi instrumental untuk menetapkan instumen yang digunakan pemerintah dalam melakukan pemerintahan dan fungsi jaminan untuk menjamin adanya perlindungan hukum bagi warga masyarakat. Fungsi normatif hukum administrasi negara dilakukan dengan menelaah serangkaian peraturan perundang-undangan. Setiap tindakan pemerintah harus didasarkan pada asas legalitas, yang berarti terlebih dahulu mencari dasar hukum tindakan dalam undangundang. ${ }^{20}$ Jika tidak terdapat dalam undang-undang, pemerintah mencari dalam berbagai peraturan perundang-undangan yang terkait. Apabila tidak ditemukan legalitasnya dan harus dilakukan tindakan segera, maka pemerintah dapat menggunakan kewenangan bebas yang disebut freies ermessen. Pelaksanaan freies ermessen harus memperhatikan asas-asas umum pemerintahan yang baik. ${ }^{21}$

\footnotetext{
18 Nurus Zaman, "Membangun Politik Hukum Administrasi Pemerintahan Yang Bersumber Dari Nilai-Nilai Pancasila."

19 Bagir Manan, Sistem Peradilan Berwibawa: Suatu Pencarian (Jakarta: Mahkamah Agung RI, 2014).

20 Aidul Fitriciada Azhari, "Negara Hukum Indonesia: Dekolonisasi Dan Rekonstruksi Tradisi," Jurnal Hukum Ius Quia Iustum 19, no. 4 (2012): 489-505, https://doi.org/10.20885/iustum.vol19.iss4.art1.

${ }^{21}$ Hans Kelsen, Generaly Theory of Law (New York: Russel And Russel, 1971).
} 
Asas legalitas meski menjadi tumpuan utama dalam negara hukum, tetapi dalam hal-hal tertentu asas tersebut dapat disimpangi misalnya asas legalitas dalam hal pidana wajib dijadikan sebagai dasar, karena menyangkut perlindungan hak asasi manusia. Sedangkan asas legalitas dalam penyelenggaraan pemerintahan dipandang sebagai bentuk menghindari dari sikap sewenang-wenang dari penguasa, tetapi bukan menjadi terpenting karena esensi dari penyelenggaraan pemerintahan adalah mewujudkan kesejahteraan bagi warga masyarakat. Kemudian fungsi instrumen hukum administrasi negara dimaksudkan untuk menciptakan kelancaran penyelenggaraan pemerintahan. Akhirnya fungsi jaminan hukum administrasi negara harus dapat memberikan perlindungan warga masyarakat sehingga tercapai keadilan dan kesejahteraan secara merata. Penggunaan kekuasaan negara terhadap warga masyarakat bukanlah tanpa persyaratan. Warga masyarakat tidak dapat diperlakukan secara sewenang-wenang sebagai obyek. Keputusan dan/atau tindakan terhadap warga masyarakat harus sesuai dengan ketentuan peraturan perundang-undangan dan asas-asas umum pemerintahan yang baik.

Penyelenggaraan kekuasaan negara harus berpihak kepada warga masyarakat dan bukan sebaliknya. Undang-undang administrasi pemerintahan harus mengatur paradigma yang dapat menguntungkan bagi warga negara. Kesan bahwa warga masyarakat cenderung dijadikan sebagai obyek saat ini harus dibalik bahwa warga masyarakat menjadi subyek. Hubungan yang seimbang antara warga masyarakat dengan negara harus dijadikan sebagai ukuran awal dalam setiap pembentukan peraturan perundang-undangan. Dengan demikian, posisi antara dua elemen antara negara dan warga negaranya menjadi seimbang dan setara. Kedudukan yang seimbang antara warga masyarakat dengan negara bukan berarti warga negara dapat melakukan tindakan diluar ketentuan peraturan perundang-undangan,tetapi itu dimaksudkan bahwa hak-hak dari warga negara yang sudah dirinci dan diatur dalam UUD 1945 segera diimpelementasikan dan diwujudkan oleh negara. Dengan demikian, tanggungjawab negara dan/atau pemerintahan menjadi nyata.

\section{B. Sinergitas Asas-Asas Pancasila Dalam Hukum Administrasi}

Dengan ditetapkannya Pancasila sebagai Staatsfundamentalnorm, maka pembentukan hukum, penerapan, dan pelaksanaannya tidak dapat dilepaskan dari nilai nilai Pancasila. Namun, dengan penempatan Pancasila sebagai Staatsfundamentalnorm berarti menempatkannya di atas Undang-Undang Dasar. Secara yuridis ketatanegaraan, Pancasila merupakan dasar negara Republik Indonesia sebagaimana terdapat pada Pembukaan Undang-Undang Dasar Negara Republik Indonesia tahun 1945, yang kelahirannya ditempa dalam proses kebangsaan Indonesia. Pancasila perlu diaktualisasikan agar dalam praktik berdemokrasinya tidak kehilangan arah dan dapat meredam konflik yang tidak produktif. 
Berlakunya Undang-undang Nomor 30 Tahun 2004 tentang Administrasi Pemerintahan kian melengkapi dan memperkuat peranan Peradilan Tata Usaha Negara dalam tertib hukum administrasi di Indonesia, dan sebagai landasan politik hukum bagi penegakan hukum administrasi negara. ${ }^{22}$

Eksistensi Pancasila dalam hukum administrasi negara mengatur kewenangan, tugas, fungsi, dan tingkah laku penyelenggara negara sebagai pejabat adiministrasi negara. Negara mengatur kebijakan administratif negara dalam menggerakkan organ negara sehingga dengan norma kaidah hukum administrasi. ${ }^{23}$

Hukum administrasi negara bekerja secara efektif melalui administrasi pemerintahan dalam mengatur interaksi administrasi negara dengan rakyat, sehingga rakyat merasa terpenuhi kebutuhan pelayaan publiknya. Integrasi nilainilai Pancasila dalam hukum administrasi negara perlu diperkuat, karena Pancasila adalah "sumber dari hukum admiistrasi negara, sehingga Pancasila menjadi pilar utama dalam impelementasi hukum administrasi negara, terutama dalam menggerakkan jabatan atau alat-alat perlengkapan." 24 Bekerjanya hukum administrasi negara berdasarkan pada Pancasila yakni dengan mengimplemetasikan nilai Pancasila dalam menggerakkan alat kelengkapan negara secara dinamis sesuai dengan Pancasila, karena Pancasila selain sebagai sumber hukum, Pancasila dijadikan sebagai asas dan filosofi bagi pemerintah dalam menjalankan roda pemerintahan. Pancasila dianggap mampu mempersatukan seluruh elemen bengsa dengan sila ketiga persatuan Indonesia dengan semangat kebhinekaan.

Nilai-nilai Pancasila yang selayaknya disinergiskan hukum administrasi Negara adalah sebagai berikut:

a. Sila Pertama, Ketuhanan Yang Maha Esa

Sila Ketuhanan Yang Maha Esa berorientasi pada pengalaman nilai-nilai Ketuhanan dengan objeknya adalah manusia makhluk ciptaan Allah SWT. Ketika dikaji pembukaan Undang-Undang Dasar Tahun 1945 yang terletak pada aline kedua yang menyatakan bahwa "atas berkat rahmat Allah Yang Maha Kuasa dan didorongkan oleh keinginan luhur, supaya berkehidupan berkebangsaan yang bebas, maka rakyat Indonesia menyatakan dengan ini kemerdekaannya." Sila pertama dari Pancasila ini dapat dioperasionalkan seperti: "setiap orang Indonesia seharusnya beriman kepada Tuhan Yang Maha Esa, yang wujud perilakunya adalah menjalankan perintah ajaran agamanya masing, bertoleransi terhadap orang lain yang menjalani ajarannya agamanya."

\footnotetext{
${ }^{22}$ Iskatrinah, "Pergeseran Kompetensi Peradilan Tata Usaha Negara Pasca Diundangkan UndangUndang Nomor 30 Tahun 2014 Tentang Administrasi Pemerintahan."

${ }^{23}$ Fais Yonas Bo'a, "Pancasila Sebagai Sumber Hukum Dalam Sistem Hukum Nasional Pancasila as the Source of Law in the National Legal System." 2013).

${ }_{24}$ Teguh Prasetyo, Hukum Dan Sistem Hukum Berdasarkan Pancasila (Yogyakarta: Media Perkasa,
} 
Kemudian mengamalkan ajaran agama betul memberi manfaat baagi kepentingan orang lain/banyak. ${ }^{25}$

Dalam kehidupan berbangsa dan bernegara yang relevan dengan nilai dasar sila pertama Ketuhunan Yang Maha Esa yakni negara menjamin kemerdekaan tiap-tiap penduduk untuk memeluk agamanya masing-masing dan untuk beribadat menurut agamanya dan kepercayaannya. Dengan demikian negara hendaknya melindungi warga negara alam menjalankan peribadatan sesuai keyakinan dan kepercayaannya. Pancasila mengajarkan prinsip toleransi beragama yang semestinya dibangun pemahaman mendasar dan fundamental mengenai toleransi beragama yang dijabarkan dalam bentuk kurikulum pendidikan.

Penataan kurikulum pendidikan, terutama kurikulum pendidikan hukum dalam mata kuliah hukum tata negara dan hukum administrasi negara, memberikan pembelajaran tentang eksistensi organ negara yang dibingkai dalam ajaran ketuhanan berdasar pada prinsip sila pertama Ketuhanan Yang Maha Esa. Sinergitas ilmu hukum dalam sebuah konstruksi kurikulum dengan nilai religius berbasis ketuhan, dimana organ dan negara meskipun tidak dimasukkan dalam sistem pemerintahan, kerena Indonesia bukan negara Islam tetapi negara orang yang beragama, sehingga diperlukan penguatan nilai ke-Tuhanan yang ada dalam penyelenggara negara dalam konteks hukum administrasi negara adalah "alat atau pejabat perlu mengaplikasi nilai ke-Tuhanan, penerapan nilai ketuhanan diawali dengan nilai internalisasi ilmu hukum baik hukum tata negara dan hukum administrasi negara dalam kerangka etik moral ketuhanan sebagaimana yang terdapat dalam sila pertama Ketuhanan Yang Maha Esa."

b. Sila Kedua, Kemanusiaan Yang Adil Dan Beradab

Nilai-nilai kemanusiaan hendaknya menjamin kemandirian individu, persamaan derajat manusia, rasa solidaritas dan kepedulian sosial, sehingga dalam kerangka operasional kurikulum pendidikan hukum dalam mata kuliah Hukum Tata Negara dan Administrasi Negara idealnya menghasilkan lulusan sarjana hukum yang tidak individualisme yang tidak mau berbagi ilmu serta menularkan pengetahuan kepada yang membutuhkan dan tidak memiliki sifat materialisme yang mengukur dan menakar keilmuannya dengan angka rupiah dah harga serta mengadaikan idealism keilmuannya. Hasil dari produk kurikulum yang berbasis kemanusiaan yang adil dan beradab akan melahirkan sarjana hukum yang memanusiakan manusia, memiliki sifat penghargaan yang tinggi terhadap nilainilai kemanusiaan.

25 Sutan Syahrir Zabda, "Aktualisasi Nilai-Nilai Pancasila Sebagai Dasar Falsafah Negara Dan Implementasinya Dalam Pembangunan Karater Bangsa,” Jurnal Pendidikan Ilmu Sosial 11, no. 9 (2016): 14156. 
Letak esensi sila kedua Kemanusiaan Yang Adil Dan Beradab adalah "mampu menciptakan sarjana hukum yang menjunjung tinggi nilai-nilai keadilan, sehingga menjadi manusia yang beradab, bukan biadab terhadap sesamanya, karena sila kedua secara edukatif mengajarkan nilai keluhuran budi, kesopanan dan kesusilaan yang merupakan bagian dari kebudayaan bangsa."

c. Sila ketiga, Persatuan Indonesia

Filosofi yang sangat mendalam dalam sila ketiga yakni Persatuan Indonesia memberi makna bahwa Indonesia nation state atau negara kebangsaan, karena terdiri dari berbagai entitas golongan, suku, agama, kepentingan, serta beragamnya berbagai karakteristik budaya dari Sabang sampai Merauke dan dari pulai Nias ke pulau Rote. Persatuan Indonesia dalam sila ketiga Pancasila, mampu mempersatukan dalam sebuah kebulatan tekad kebersamaan di tengah keberagaman bangsa dengan menyatukan ideologi, ekonomi, politik, keamanan dan sosial budaya.

Menyatunya berbagai elemen bangsa akan membuat negara kokoh dan kuat dari berbagai ancaman disintegrasi bangsa. Konteks hukum tata negara dan hukum administrasi negara jika dikembangkan dalam kurikulum pendidikan hukum di pasal 1 ayat (3) Undang-Undang dasar tahun 1945 menyatakan bahwa "Negara Indonesia adalah negara hukum" yang mengandung arti bahwa pelaksanaan organ dan alat negara hendaknya tetap berada pada koridor negara hukum bukan negara kekuasaan. Sila ketiga, Persatuan Indonesia memberikan makna yang esensial bagi landasan kelangsungan Negara Kesatauan Republik Indonesia $(\mathrm{NKRI}){ }^{26}$

d. Sila keempat, Kerakyatan Yang Dipimpin Oleh Hikmat Kebijaksaan Dalam Pemusyawaratan Perwakilan

Sila keempat mengandung nilai penguatan kedaulata rakyat dengan prinsip musyawarah untuk mencapai mufakat dengan menjamin kebebasan berdemokrasi. Demokrasi permusyawaratan yang dimaknai sebagai persaudaraan dan kekeluargaan dalam mencapai kata mufakat. Nilai kedaulatan berarti "mewujudkan kedaulatan rakyat dan kedaulatan hukum." Kedaulatan hukum dengan kekuasaan tertinggi pada hukum, sehingga hukum menjadi kiblat kehidupan bernegara dan hukum menjadi penglima, sedangkan kedaulatan rakyat menempatkan rakyat akan menciptakan keseimbangan negara, karena kedaulatan rakyat serta demokrasi berpijak pada politik sedangkan kedaulatan hukum atau nomokrasi berpijak pada hukum.

e. Keadilan Sosial Bagi Seluruh Rakyat Indonesia

\footnotetext{
26 Wawan Fransisco, “Jurnal Hukum Progresif” 11, no. 1 (2017): 1828-37, https://doi.org/https://doi.org/10.33019/progresif.v11i1.196.
} 
Perspektif hukum nilai keadialan sosial mengandung makna keadilan sosial dan ekonomi dengan menghadirkan ekonomi kerakyatan yang ramah terhadap usaha kecil yang merupakan cerminan nilai Pancasila yang berkeadilan sosial bagi seluruh rakyat Indonesia, sehingga melahirkan kewajiban negara dalam bentuk kebijakan ekonomi yang berpijak pada kesejahteraan rakyat. Demikian halnya dalam meningkatkan kesejahteraan rakyat. Cita-cita ideal distribusi keadilan dalam negara-bangsa yang diterjemahkan dalam kebijakan yang telah majemuk, kemajemukan masyarakat diikat oleh sila dikonsultasikan kepada publik sehingga dapat dilihat kelima Pancasila yang berbunyi: "Keadilan sosial apakah negara benar-benar dapat mewujudkan bagi seluruh rakyat Indonesia." 27 Konstitusi sangat jelas memberikan pernyataan bernegara dalam pembukaan undang-undang dasar tahun 1945 yang menyatakan bahwa mewujudkan keadilan sosial bagi seluruh rakyat Indonesia. Prinsip negara hukum mengedepankan keadilan sehingga masyarakat akan merasakan keadilan hukum menuju kesejahteraan rakyat.

\section{PENUTUP}

Hukum administrasi dan sistem peradilan di Indonesia yang berkeadilan sesuai asas-asas Pancasila merupakan kristalisasi nilai-nilai yang hidup dan berkembang dalam masyarakat sejatinya menjadi sumber utama dalam pembentukan hukum administrasi pemerintahan. Landasan ideal yang terformulasi sebagai dasar negara dan terumus dalam lima sila pada hakikatnya mengandung ajaran moral bangsa, ajaran tentang akhlak, bagaimana seseorang bertingkah laku yang baik, yang beretika, bersusila. Sinergitas asas-asas Pancasila sangat relevan dengan hukum administrasi dengan cita-cita bernegara dalam mewujudkan demokrasi yang berpijak pada politik dan nomokrasi yang berpijak pada kedaulatan hukum, sehingga semangat bernegara yang terilhami dalaml lima sila Pancasila dalam diwujudkan dalam kehidupan berbangsa dan bernegara.

\section{DAFTAR PUSTAKA}

A. Syafi' AS. "Pengaruh Nilai-Nilai Pancasila Dan Ajaran Islam Terhadap Tujuan

Pendidikan Nasional.” Jurnal Sumbula 1, no. 1 (2016).

Anggara, Syahya. Hukum Administrasi Negara. Bandung: Pustaka Setia, 2018.

Asshidqie, Jimly. Konstitusi Bernegara Praksis Kenegaraan Bermartabat Dan

Demokratis. Malang: Setara Press, 2015.

Astomo, Putera. "Eksistensi Peradilan Administrasi Dalam Sistem Negara Hukum

Indonesia." Masalah-Masalah Hukum 43, no. 3 (2014): 363-71. https://doi.org/10.14710/mmh.43.3.2014.363-371.

27 Lismanto and Utama, "Membumikan Instrumen Hukum Administrasi Negara Sebagai Alat Mewujudkan Kesejahteraan Sosial Dalam Perspektif Negara Demokrasi.” 
p-ISSN : 2541-2345, e-ISSN : 2580-8842

Atmadja, Dewa Gede. "Asas-Asas Hukum Dalam Sistem Hukum." Kertha $\begin{array}{lllll}\text { Wicaksana } & 12, & \text { no. } & 2 & \text { (2018): }\end{array}$ https://doi.org/https://doi.org/10.22225/kw.12.2.721.145-155.

Azhari, Aidul Fitriciada. "Negara Hukum Indonesia: Dekolonisasi Dan Rekonstruksi Tradisi." Jurnal Hukum Ius Quia Iustum 19, no. 4 (2012): 489505. https://doi.org/10.20885/iustum.vol19.iss4.art1.

C.S.T Kansil dan Chritine S.T. Kansil. Empat Pilar Berbangsa Dan Bernegara. Jakarta: Rineka Cipta, 2014.

Dani Pinasang. "Falsafah Pancasila Sebagai Norma Dasar (Grundnorm) Dalam Rangka Pengembanan Sistem Hukum Nasional." Jurnal Hukum UNSRAT 20, no. 3 (2013).

Fais Yonas Bo'a. "Pancasila Sebagai Sumber Hukum Dalam Sistem Hukum Nasional Pancasila as the Source of Law in the National Legal System." Jurnal $\begin{array}{lllll}\text { Konstitusi } & 15, & \text { no. } & 1 & \text { (2018): }\end{array}$ https://doi.org/https://doi.org/10.31078/jk1512.

Faisal, Faisal. "Membangun Politik Hukum Asas Legalitas Dalam Sistem Hukum Pidana Indonesia.” Jurnal Hukum Ius Quia Iustum 21, no. 1 (2014): 81-95. https://doi.org/10.20885/iustum.vol21.iss1.art5.

Ferry Irawan Febriansyah. “DiH Jurnal Ilmu Hukum” 13, no. 25 (2017): 1-27.

Fransisco, Wawan. "Jurnal Hukum Progresif" 11, no. 1 (2017): 1828-37. https://doi.org/https://doi.org/10.33019/progresif.v11i1.196.

Hidayat, Arif, and Zaenal Arifin. "Politik Hukum Legislasi Sebagai SocioEquilibrium Di Indonesia.” Jurnal Ius Constituendum 4, no. 2 (2019): 14759. https://doi.org/10.26623/jic.v4i2.1654.

Iskatrinah. "Pergeseran Kompetensi Peradilan Tata Usaha Negara Pasca Diundangkan Undang-Undang Nomor 30 Tahun 2014 Tentang Administrasi Pemerintahan." Jurnal Media Komunikasi Pendidikan Pancasila Dan Kewarganegaraan Volume 2, no. 1 (2020): 200-207. https://doi.org/https://doi.org/10.23887/jmpppkn.v2i1.137.

Kelsen, Hans. Generaly Theory of Law. New York: Russel And Russel, 1971.

Lismanto, Lismanto, and Yos Johan Utama. "Membumikan Instrumen Hukum Administrasi Negara Sebagai Alat Mewujudkan Kesejahteraan Sosial Dalam Perspektif Negara Demokrasi.” Jurnal Pembangunan Hukum Indonesia 2, no. 3 (2020): 416-33. https://doi.org/10.14710/jphi.v2i3.416-433.

Manan, Bagir. Sistem Peradilan Berwibawa: Suatu Pencarian. Jakarta: Mahkamah Agung RI, 2014.

Moleong, Lexy J. Metode Penelitain Kualitatif. Bandung: PT Remaja Rosda Karya, 2016.

Novita Eleanora, Fransiska. "Pancasila Sebagai Norma Dasar Dalam Sistem Hukum Indonesia.” ADIL: Jurnal Hukum 3, no. 1 (2019): 141. 
https://doi.org/10.33476/ajl.v3i1.838.

Nurus Zaman. "Membangun Politik Hukum Administrasi Pemerintahan Yang Bersumber Dari Nilai-Nilai Pancasila." Rechtldee 10, no. 2 (2015): 203-22. https://doi.org/https://doi.org/10.21107/ri.v10i2.1237.

Prasetyo, Teguh. Hukum Dan Sistem Hukum Berdasarkan Pancasila. Yogyakarta:

Media Perkasa, 2013.

Sutan Syahrir Zabda. "Aktualisasi Nilai-Nilai Pancasila Sebagai Dasar Falsafah

Negara Dan Implementasinya Dalam Pembangunan Karater Bangsa.” Jurnal

Pendidikan Ilmu Sosial 11, no. 9 (2016): 141-56.

Widiatama, Hadi Mahmud, Suparwi. "Ideologi Pancasila Sebagai Dasar

Membangun Negara Hukum Indonesia." Jurnal USM Law Review 3, no. 2 (2020): 310-27. https://doi.org/http://dx.doi.org/10.26623/julr.v3i2.2774.

A. Syafi' AS. 'Pengaruh Nilai-Nilai Pancasila Dan Ajaran Islam Terhadap Tujuan

Pendidikan Nasional.” Jurnal Sumbula 1, no. 1 (2016).

Anggara, Syahya. Hukum Administrasi Negara. Bandung: Pustaka Setia, 2018.

Asshidqie, Jimly. Konstitusi Bernegara Praksis Kenegaraan Bermartabat Dan Demokratis. Malang: Setara Press, 2015.

Astomo, Putera. "Eksistensi Peradilan Administrasi Dalam Sistem Negara Hukum Indonesia." Masalah-Masalah Hukum 43, no. 3 (2014): 363-71. https://doi.org/10.14710/mmh.43.3.2014.363-371.

Atmadja, Dewa Gede. "Asas-Asas Hukum Dalam Sistem Hukum." Kertha $\begin{array}{lllll}\text { Wicaksana } & 12, & \text { no. } & 2 & \text { (2018): }\end{array}$ https://doi.org/https://doi.org/10.22225/kw.12.2.721.145-155.

Azhari, Aidul Fitriciada. "Negara Hukum Indonesia: Dekolonisasi Dan Rekonstruksi Tradisi." Jurnal Hukum Ius Quia Iustum 19, no. 4 (2012): 489505. https://doi.org/10.20885/iustum.vol19.iss4.art1.

C.S.T Kansil dan Chritine S.T. Kansil. Empat Pilar Berbangsa Dan Bernegara. Jakarta: Rineka Cipta, 2014.

Dani Pinasang. "Falsafah Pancasila Sebagai Norma Dasar (Grundnorm) Dalam Rangka Pengembanan Sistem Hukum Nasional." Jurnal Hukum UNSRAT 20, no. 3 (2013).

Fais Yonas Bo'a. "Pancasila Sebagai Sumber Hukum Dalam Sistem Hukum Nasional Pancasila as the Source of Law in the National Legal System." Jurnal $\begin{array}{llllll}\text { Konstitusi } & 15, & \text { no. } & 1 & \text { (2018): }\end{array}$ https://doi.org/https://doi.org/10.31078/jk1512.

Faisal, Faisal. "Membangun Politik Hukum Asas Legalitas Dalam Sistem Hukum Pidana Indonesia.” Jurnal Hukum Ius Quia Iustum 21, no. 1 (2014): 81-95. https://doi.org/10.20885/iustum.vol21.iss1.art5.

Ferry Irawan Febriansyah. "DiH Jurnal Ilmu Hukum” 13, no. 25 (2017): 1-27.

Fransisco, Wawan. “Jurnal Hukum Progresif” 11, no. 1 (2017): 1828-37. 
https://doi.org/https://doi.org/10.33019/progresif.v11i1.196.

Hidayat, Arif, and Zaenal Arifin. "Politik Hukum Legislasi Sebagai SocioEquilibrium Di Indonesia.” Jurnal Ius Constituendum 4, no. 2 (2019): 14759. https://doi.org/10.26623/jic.v4i2.1654.

Iskatrinah. "Pergeseran Kompetensi Peradilan Tata Usaha Negara Pasca Diundangkan Undang-Undang Nomor 30 Tahun 2014 Tentang Administrasi Pemerintahan." Jurnal Media Komunikasi Pendidikan Pancasila Dan Kewarganegaraan Volume 2, no. 1 (2020): 200-207. https://doi.org/https://doi.org/10.23887/jmpppkn.v2i1.137.

Kelsen, Hans. Generaly Theory of Law. New York: Russel And Russel, 1971.

Lismanto, Lismanto, and Yos Johan Utama. "Membumikan Instrumen Hukum Administrasi Negara Sebagai Alat Mewujudkan Kesejahteraan Sosial Dalam Perspektif Negara Demokrasi." Jurnal Pembangunan Hukum Indonesia 2, no. 3 (2020): 416-33. https://doi.org/10.14710/jphi.v2i3.416-433.

Manan, Bagir. Sistem Peradilan Berwibawa: Suatu Pencarian. Jakarta: Mahkamah Agung RI, 2014.

Moleong, Lexy J. Metode Penelitain Kualitatif. Bandung: PT Remaja Rosda Karya, 2016.

Novita Eleanora, Fransiska. "Pancasila Sebagai Norma Dasar Dalam Sistem Hukum Indonesia." ADIL: Jurnal Hukum 3, no. 1 (2019): 141. https://doi.org/10.33476/ajl.v3i1.838.

Nurus Zaman. "Membangun Politik Hukum Administrasi Pemerintahan Yang Bersumber Dari Nilai-Nilai Pancasila." Rechtldee 10, no. 2 (2015): 203-22. https://doi.org/https://doi.org/10.21107/ri.v10i2.1237.

Prasetyo, Teguh. Hukum Dan Sistem Hukum Berdasarkan Pancasila. Yogyakarta: Media Perkasa, 2013.

Sutan Syahrir Zabda. "Aktualisasi Nilai-Nilai Pancasila Sebagai Dasar Falsafah Negara Dan Implementasinya Dalam Pembangunan Karater Bangsa.” Jurnal Pendidikan Ilmu Sosial 11, no. 9 (2016): 141-56.

Widiatama, Hadi Mahmud, Suparwi. "Ideologi Pancasila Sebagai Dasar Membangun Negara Hukum Indonesia." Jurnal USM Law Review 3, no. 2 (2020): 310-27. https://doi.org/http://dx.doi.org/10.26623/julr.v3i2.2774. 